\author{
Ana Ashtalkovska Gajtanoska (North Macedonia) \\ Institute of Ethnology and Anthropology \\ Faculty of Natural Sciences and Mathematics \\ Ss. Cyril \& Methodius - Skopje \\ E-mail: ashtalkovska@gmail.com.mk
}

\author{
"THE NATIONALITY OF FOLKLORE" \\ -ILLUSTRATED BY EXAMPLES FROM THE JOURNAL \\ "MACEDONIAN FOLKLORE" AND ITS PUBLICATIONS FROM 1968 \\ UNTIL 1991-
}

\begin{abstract}
The nationality of folklore" is a title inspired by the vast number of articles in the journal "Macedonian Folklore" that deals with the establishment of the Macedonian national affiliation of the folklore as one of the main goals of Macedonian folkloristics. The main interest in this article is focused on the treatment of folklore in the period of ex-Yugoslavia, with a particular emphasis on the idealized, subjective, ideologically, and patriotically burdened narration concerning the folklore and its bearers.
\end{abstract}

Keywords: folklore, Macedonia, "the people," uniqueness, identity.

\title{
Introduction
}

In the public discourse, as well as in the scientific discourse, when it comes to the so-called "national scientific disciplines," the attitude towards the researchers who have to guard, take care of, often (re)create and strengthen the Macedonian national identity is still quite popular. Concerning the fact that the right-oriented government in Macedonia until recently has been popularizing this very position using different state mechanisms (media, education, etc.), it can be stated that the tasks of the disciplines burdened by a load of being "national" actually gain their legitimacy and continuity, instead of them being finally deconstructed. In that sense, it is interesting to analyze the very beginning of the development of this discourse illustrated by the examples of the journal "Macedonian folklore," published by the Institute of folklore in the Yugoslav period.

The main ideological aspects of the Yugoslav period, such as brotherhood and unity, equality, etc., do not imply national and nationalistic tone of the researches carried by the "national disciplines." On the contrary, absolute 
relaxation of ethnocentrism would have been more logical, since the control of socialistic ideology and politics covered all spheres of life, including science. According to the examples from the journal "Macedonian folklore," it turns out that the burden of the national is actually what marks this period. For the needs of this research, 48 issues of the journal are analyzed, published in the socialistic period: from the first edition published in 1968 , until issue number 48 , published in 1991.

The Institute of Folklore was established in 1950, and it is one of the institutions that have a long history in the Republic of Macedonia in terms of research of folklore and folk art as cultural heritage. Since its establishment, there was a special bond between this institution and Macedonian people, often identified by the authors as "our people." In a sense, we can speak of the advocacy of the Macedonian people by folkloristics in this period. This is additionally evident by the Institute tasks stated in the period of its establishment: "the folkloristic treasure of Macedonian people, purification of national folklore, distribution of our folk art, care for the purity and authenticity of the folklore and our folk art" etc. (my emphasis) Ристовски 1970: 5). Although in 1962, renaming of the Institute of Folklore resulted in some professionalization of the Institute's main tasks, that is, from that moment on, the above-highlighted terms are not mentioned anymore. However, in the majority of authors' discourse in the journal, the commitments that underline these terms remain current. Thus, the Institute is obliged to gather, keep, and preserve, to present, reflect, and express the Macedonian folklore as the confirmation of the ethnic, cultural, and national identity of the Macedonians. The question of how an institution such as the Institute of Folklore is involved in the "scientific" creation and (re)creation of the national identity is explored further in the text, which at the same time is a good illustration of what Naumovic calls "the double insider syndrome" when it comes to the researchers from "national disciplines" (Mihăilescu, Iliev, Naumović 2008: $14,15)$.

\section{Romantic nationalism}

"Whenever nations turn to their folkloristic past to find faith in themselves and courage for the future, they are following lines laid down by

Herder."

(Wilson 1973: 832).

The strong national and nationalistic tones in the folklorist's analysis during socialism in Macedonia are, as Ines Prica says, vague and unclear, more that they are logical, having in mind the declared position of socialistic ideology against nationalism (see Prica 2004/2005: 15). The researchers from these disciplines are traditionally occupied with their own, mainly rural folk culture, with the reconstruction of its past, practicing the positivistic approach, neglecting the theory, explanations, analysis, focusing upon the description, and working 
under a significant influence of the nation-building and communistic ideology ${ }^{1}$ (see Čapo 2014: 56). Due to these aspects, folkloristic studies, ethnology, and other "national disciplines" in Central and Southeast Europe are treated as outdated and backward, meaning that they have nothing to offer to Western anthropology. It has to be stated that this label cannot be applied to all scientific disciplines in this broad region because there are significant variations in this sense. Even in the frames of SFR Yugoslavia, the centers such as Belgrade, Zagreb, and Ljubljana relatively early in their history have abandoned the ethnocentric concept, which is not the case with the peripheries such as Skopje. According to Risteski, the establishment of the Institute of Folklore as the only institution of this kind in SR Macedonia fits the socialistic ideology in favor of controlling the nationalistic rhetoric supported or promoted by the science; that is why this solution was considered as a safe choice. He thinks that this solution harmed and marginalized ethnology at the very start since ethnology was treated as more dangerous in relation to opening national questions in Macedonia (Ристески 2014: 60). Still, according to the analysis of the journal "Macedonian folklore" and its editions published in the socialistic period, it can be stated the promotion of romantic nationalism as a long term tendency during the Yugoslav period. The romantic nationalism inspired by Herder left traces, especially in Central and Eastern Europe (Wilson 1973: 830). According to Herder's epistemological base from the 19 century, the nation is an organic entity, the folk spirit is a base of its originality, and it exists through the history as something unique, static, authentic. So the folklore or different aspects of the folk culture are maintaining the national identity through time and determine its specificity. There lies the fascination with the rural culture (see Vukov 2012: 335). When the researcher of folklore or any other aspect of the folk culture is a member of the researched culture, she/he shares plenty of cultural values and knowledge with the interlocutors and when added Herder's guidelines for the folklore as a source of the folk spirit that is the essence of national identity, the deliberate ideologization of the researched problem seems like a logical consequence. In this way, the researchers from those "national disciplines" become ideologues of the nation (see Mihăilescu, Iliev, Naumović 2008: 14, 15).

\section{Historical poetics and pathetic}

According to Herder's guidelines, folklore is used as a tool of bridging the gap between the past and the present, and it contains the national spirit. Folklore can also explain the history and can offer otherwise unavailable data for the past epochs (Wilson 1973: 825). The editions of the journal "Macedonian folklore" during the Yugoslav period are rich with articles that deal with the

1 . In this context it is interesting how the ethnocentric discourse in the analysis in the journal "Macedonian folklore" is compensated with a large number of articles that by all means are suitable for the ruling socialistic ideology, especially those dedicated to the comrade Tito and the partisan folk songs also susceptible to the strong idealization by the authors. 
historical or revolutionary folk songs which are probably suitable for the needs of the young Macedonian nation and the attempts to consolidate its historical narration. In a sense, we can state that the revivalist guidelines have been crystallized during socialism. The traditional song is in a close relationship with the Macedonian identity and its promotion; it represents, affirms, and proves the Macedonian national identity. Because of this, the folkloristics and its historical interpretations are glorifying this kind of folklore as hugely significant for the Macedonian nation: "That song, as all the folklore, represents the testimony for the national traditions of the people, for its national consciousness and being, a testimony that cannot be in any case simply ignored, negated and disputed. The Macedonian historical folk song contains all these aspects of the Macedonian nation and not only that, but it manifests them, it emphasizes them and celebrates them with all its power" (Робовски 1968: 45). The Ilinden uprising is an especially suitable moment in history for connecting it with the centuriesold aspirations of Macedonian people for freedom and national independence. Through the folklore, some of the prominent historical figures from Macedonian history, additionally are being idealized, especially those from the Ilinden period. In this way, folkloristics, in the socialistic period, participates in building and stabilizing certain narrations about the historical past. The focus on the historical stories means sanctification, i.e., illumination of the Macedonian history, reflected in the narratives from the analyzed poems that refer to the glorious struggles of the Macedonian people.

Additionally, folkloristics treats the revolutionary folk art as a valid, accurate historical interpretation about the glorious past of Macedonian people. The folkloristic analyses in frames of the idealization of the folk and the national, especially when it comes to the folklore connected to historical events, are promoters of patriotism, identified as the highest human value. Besides the folklore that highlights patriotism, folkloristics does the same supported by the educational role of folklore that is supposed to teach youngsters about this important kind of love towards the homeland and the people. Due to the influence of foreign nationalisms and propaganda of the neighbors, the highlighting of what is "Macedonian" in people is not interpreted as romanticism or nationalism but as an essential need that springs from the depth of the heart and soul of Macedonian individual (Вражиновски 1976: 103, 104). In that context it becomes easy for the idealization of the folk culture to be identified with the idealization of the Macedonian: "One of the important points of telling memories is the Macedonian spirit and Macedonian national feeling as well as the intolerance of this spirit for different influences and propagandas (...) this testifies that our people do not stay aside from all that happens around which affects the integrity of our homeland. Macedonian people are not indifferent, but they comment and say their words every time in the spirit of the common people's perceptions and ideals of Macedonians" (Вражиновски 1976: 103, 104). In order to highlight shared people's or shared Macedonian characteristics, the authors often use terms as: Macedonian man, our man, folk genius, the 
Macedonian woman, anonymous folk creator, etc. - i.e., one representative of the people where all critical aspects of what is Macedonian are being met. This tendency directly illustrates the positivistic approach in researching "the people" that is treated as a unique organism without deviances: "the image of the people that exist as a unique organism by its spirit and directionality" (Најчески 1969: 84). In this case, the folklorists also remain consistent with Herder's focus on the people, not on the individual, that is the idea that the individual can accomplish full achievement only as an integral part of a nation (Wilson 1973: 823).

Among the enemies of the people in the folkloristic analyses, "the Turks" are the main villains. They are qualified as Turkish tyranny and centuries-old enemy (Најчески 1968: 41), centuries-old Turkish conqueror (Робовски 1968: 42), hostile military force (Каровски 1968: 51), Asian thugs (Симитчиев 1984: 65), Turkish slavery, etc. In that way, the folkloristic analyses contain qualifications that, in addition to representing popular animosity, simultaneously represent the author's hatred towards "the Turks": "Turkish slavery has liquidated the freedom and independence of South Slavs, it has stopped their cultural development and economic life. In Balkan countries where the sword of the conqueror has been spreading death, where the terror and rape were companions in everyday life of the enslaved Christians, it seemed that every hope, joy, and faith in the future was buried forever. In those hard and unbearable circumstances, still, the 'Raya' did not hold long. They rise against the Asiatic thugs defending their honor, their folk traditions, their mother tongue" (Симитчиев 1984: 65). Having in mind these kinds of historical interpretations about Macedonian people and their century-old oppression, it becomes logical their veneration in folkloristic analyzes as a counterbalance to centuries of historical suffering. That is why the ideal representation about the people implies highlighting two extremely conflicting situations, for example: morbid violence against the Macedonian but also his unshakable nature, pride and courage: "In it a morbid image of violence convicted upon our man is given, but at the same time it celebrates his unshakable nature, the pride and courage of the Macedonian not to give up his national identity and his name" (Јаќоски 1983: 20); an epic journey through the suffering of the Macedonian, sorrow, blackness, as well as his unshakable nature, longing for freedom: "an epic journey through the suffering of the Macedonian filed with misery, blackness, sorrow, but also his unshakable nature, faced with the relativity of the injustice and with constant longing for long-expected red dawn of sunshine and freedom" (Стоичковски 1990: 163). Folkloristics on the Balkans in times of nation-building offers the critical element in the revival of the past and in creating a model for the development of the nations. According to that, the folklorists are not interested only in reconstructing the past, but also in its modeling for the needs of the nations (see Wilson 1973: 833). 


\section{A multitude of contributions in favor of the national}

While the historical, revolutionary folklore can be directly linked to the ethnical and national, the themes that are not connected with these identities are again analyzed in their favor. Those kinds of connections confirm the priorities of Macedonian folkloristic studies during socialism. Historical contexts are always present even in the analyses that are not dealing with the historical or revolutionary folklore, but when for example the topic concerns the rhythm of Macedonians folk songs: "In this beautiful song which can have several variants, where a folk genius sings for the unparalleled courage and self-sacrifice of our freedom fighters from the Ilinden period, who confronted the thousand times numerous enemy military force, opposed their unprecedented and unheard of heroism and determination to die for freedom, we came across flawless symmetric distribution of the emphasized and unstressed syllables" (Каровски 1968: 51).

There are lots of examples to illustrate this tendency among Macedonian folklorists during the Yugoslav period. For example, the wedding customs are analyzed in favor of authenticity and ethnic specificity, or as a "specific, ethnically differentiated wedding art" (Стоичковски 1991: 112). In the article dedicated to the toponymic legends, those legends are easily connected to great patriotic conciseness of the Macedonian, as well as with its national specificity: "The Macedonian in the toponymic legends affirms his own high level of patriotic conciseness: the love towards his homeland and his people and the pride of belonging to a nation that was capable in the hardest historical times to hold on not losing its own national name" (Вражиновски 1979: 238, 239). These kinds of interpretations, due to their superficiality, can illustrate the idea of the folklorists' duty for connecting their fields of interest with the ethnic or national identities, glorifying what has been identified as Macedonian, even when the topics of research are not in any way connected with those identities.

In the scope of the efforts to identify or promote the ideal model of an imagined Macedonian folk culture, and as a result of the methodological limitations of the Macedonian folkloristics during this period, any distortions that fall out of the frames of the ideal model, or that are opposing it, are treated as foreign, or borrowed. An author claims that Macedonian erotic tails are based on realistic grounds of man-woman relations based in nature; it means that pathological sexual relations cannot be related to "our people." Our erotic stories mostly deal with real themes of a man-woman relationship, based on natural foundations. The stories of pathological sexual relations are sporadic, and they are alien to our people and utterly incompatible with people's ethical perceptions. Sexual disorders, such as homosexuality, sodomy, bestiality, incest, are almost absent in those stories. Another thing: from such rare stories, it is easy to conclude that they are not ours, Macedonian, but usually borrowed. Thus the 
rare homosexuality in the stories is connected with the imams and the priests, with the Turks, with the migrant workers" (Пенушлиски 1974: 80, 81). The idealization of folk culture through the folkloristic analyses is an essential task of the discipline always representing the Macedonian folk culture in a positive light, without deviations, pathologies, and distortions. In that way, besides the folklore, which often idealizes and romanticizes the themes, the folkloristic analyses are contributing with an additional layer of idealization, which certainly exceeds the frames of the professional tasks of this "national discipline." The aim of this practice is explained by Čolović in the following way: "In order for that data to serve as a firm and convincing base for the national identity and for the politics that has the goal to secure the survival and development of the so-called 'national being', the folkloristic data is selected, classified and transcribed. Doing this process, all the contradictions and other logical, aesthetic, or moral weaknesses are being removed" (Čolović 1994: 86).

\section{The folklore as the "national property."}

The Macedonian folkloristics actively dedicates to the commitment to protest against the appropriation of Macedonian folklore by the neighboring states. It declares that the typical characteristics of folklore with the neighboring nations are acceptable, still insisting on "our typical characteristics" contributes to nationalizing of the folklore. While Serbian, and especially Bulgarian folkloristics, treats Macedonian folklore as Serbian, or Bulgarian, Macedonian folkloristics is dedicated to the searching and highlighting of the original, typical, specific characteristics that are identified as merely Macedonian. This practice often goes along with the obsession with the origin, or search for the "homeland" of specific segments of folklore. For example, "the homeland of epic songs of South Slavs is in Macedonia" (Симитчиев 1968: 44). In this way, the Macedonian people, who are the bearer of the Macedonian folklore, stand out among their neighbors, who manifest long-standing tendencies to deny it on various grounds. Because of this problem, folklorists insist to regularly highlight the original character of Macedonian folklore which is ethnically bounded, created on "Macedonian soil" and with geographical unity: "Macedonian epic poetry (with the exception of some common motives known among the Serbs and the Bulgarians) has mainly an original character. It has been developed on Macedonian soil. The motives and the variants of our epic songs have geographical unity" (Симитчиев 1968: 53). This originality later can be easily connected to the national originality: "original, national character of our folk poetry" which explains the urge to discover: "the essential characteristics, thematic contents and specific tendencies by which our folk poetry is differentiated from the folk poetry of other, neighboring Slav people" (Најчески 1968: 194).

Alongside antiquity, the tradition that is nurtured through centuries, continuity and long-standing historical troubles persist an exceptional, pure, 
original, and unique culture called Macedonian (Симитчиев 1968: 53). This context explains the treatment of tradition as a long-term base of Macedonian uniqueness, and its accurate or complete passing from one generation to another as a continuity of that uniqueness since the distant past. In that way, the tradition and what it represents is static, almost fixed through centuries.

Insisting on autochthonous, original Macedonian culture can be treated as a reaction of the disputes by science in neighboring countries that generally follow the same principles. Almost all neighboring "national sciences" and state politics also have been traditionally disputing some of the crucial aspects of Macedonian national identity (language, the people, church, state name, etc.). Macedonian scientists, therefore, feel obliged to defend, highlight, point the Macedonian originality. The next quote is a suitable illustration of the need to defend. Here the external cultural influences are treated as typical, and they do not get in the way of the authenticity of national culture. But terms such as distortion (sometimes referred to as the term contamination) and purification through the prism of the national are opposing the above-mentioned tendency to treat the external influences as standard in culture: "The influences are indisputable fact; they have existed and will exist in every national culture without opposing its authenticity. Maybe in certain moments, they will distort some of its characteristics, but at the same time, purified through the national prism, they can stimulate and move some passive, but specific elements. Macedonian anonymous creator created his tonic treasure - his folk music, rich in melody, underlying harmony, and especially in rhythm. It is an original chronicle of our past and present lives" (Станковиќ Карчовска 1987: 171). In this way, folklore becomes the property of different Balkan nations, and the struggle, in this case, concerns the question of who owns Macedonian folklore? With the establishment of the Macedonian state and its institutions, especially the scientific institutions with the national character, and the Institute of folklore among them are finally in a position to defend Macedonian folklore and by doing that, to affirm Macedonian ownership: "The Macedonian folk poetry is represented as Bulgarian in this publication!? Why? The Bulgarian people, also as the Macedonian people, have rich and diverse folklore, so it was completely unnecessary to decorate oneself with someone else's feathers (...) Then: why the reaching after the folk riches that is not theirs?!" (Саздов 1968: 293). Because of this mission of the scientific institutions with national character, besides Macedonian people, the folklorists are being insulted by the appropriation of Macedonian folklore: "Undoubtedly such a monstrous procedure of those robbers of the cultural heritage of the Macedonian people is a great insult to the Macedonian independence, for our people in general and the Macedonian folklorists especially" (Саздов 1968: 294). This principle of taking over and defending the national identity through the mediation of folklore continues in the Balkan context, and it is still alive and current today. As can be seen from the illustrations, it is essential to make a clear cut differentiation in an ethnical and national sense, especially after the creation of the Macedonian state, which has to be different from the neighboring states 
and especially from those that are negating this vital aspect. That is why the folklore has to be nationalized (for example: "the material of pure Macedonian provenance" (Ристовски 1973: 126)), the culture, the regions etc., also and they exist as separate and exclusive within an ethnic whole - it is the unique entity, the unique cultural and national community different from neighboring ethnic regions. Nationally bounded Macedonian culture does not have a problem when songs from the folk genius from one region are accepted in some other region within ethnic Macedonia, as long as the property of the folklore is only ascribed to the Macedonians. Following Herder's thesis that two nations cannot share common characteristics (Wilson 1973: 822), this can explain the insisting on "the national affiliation of Macedonian songs" (Попвасилева 1980: 181).

\section{Methodological traps}

The practice of foreign researchers to identify Macedonian folklore as Serbian or Bulgarian is treated as: "subjective accounts about our epics by some folklorists” (Симитчиев 1968: 41). Such non-professional researchers start from the subjective ideological, and politically burdened positions when reaching and appropriating the Macedonian folklore, instead of practicing "objective" science. However, in the same context, the subjectivity of Macedonian authors is also neglected, because actually, they do the same as their Bulgarian or Serbian counterparts. All together, they are nationalizing the folklore that is treated as closed, bounded by national and ethnic borders, and the only thing that is different in this methodological approach is the national affiliation that is ascribed to it. Because of this common Balkan situation and because of the conflicts between different national folklorists struggling for the ownership of folklore in a discussion on a second symposium for Balkan folklore published in the journal "Macedonian folklore" number 9-10 in 1972, two authors warned about the dangers of that kind of "science." For example, Dushan Nedeljkovic identifies it as a nationalistic approach of exclusivity: "Well, if we talk about the epics, it seems to me that it is idealistic and fatalistic to choose one motive, one person or one type, and especially one whole song, and to ascribe it only to one specific ethnic group, that, since it has created it collectively - does not care about exclusivity. Nationalistic approach of exclusivity is something that folklore does not know about" (Дискусија 1972: 212); and Radoslav Hrovatin identifies the search for uniqueness of one's people as an old fashion tendency in ethnology: "In our research we hear very often about someone wanting to prove how something is exceptional with his people and how much it defers from other people. I think that it is very much an old fashion tendency in ethnology. I think that the modern tendency is about the search for folklore elements that are common for different ethnic groups" (Дискусија 1972: 212). Those progressive attitudes for that time do not enter the mainstream and the article that is published right after the mentioned discussion shows how difficult it is to promote such advanced views in a nationally burdened Macedonian and Balkan 
society: "The interest for its specific ethnological and folkloristic peculiarities, characteristics and specificities developed slowly and in relation to openness of Macedonia on the international scale" (Андонов-Полјански 1972: 231).

The emphasized personal connection to the topic of research is evident through the use of appropriated pronouns for crucial elements in patriotic rhetoric, such as: our country, our great-grandfathers, our people's epic, our people, our typical motives, our collectors... and many other aspects that pertain to what is "ours" as a subject of research. The research of these aspects of our own, as we have already seen, are incredibly susceptible to idealization, to the extent that only superlatives can express the Macedonian greatness: "If indeed Macedonia has the longest revolutionary history in the European space, there is no doubt that the Macedonian people built the richest and with the longest development of a revolutionary folk song not only at the Balkans but probably in the whole of Europe" (Ристовски 1976: 93). At this point, it may be useful to recall that from today's perspective, the past to which Herder's followers have returned is, for the most part, a mythical past, and the high and noble nation they tried to revive for the most part was the product of their wild imaginations (Wilson 1973: 829).

\section{Conclusion}

A crucial aspect of "national" social sciences and humanities in Macedonia and at the Balkans is to deal with topics limited by the national frames: history, ethnology, language, folklore, etc. of one's people. This methodological feature, according to the examples in the text, implies a significant limitation in the sense of practicing everything that has long been surpassed globally. This article refers to the treatment of folklore by the researchers during the Yugoslav period, and the same ethnocentric expression was again actualized during the last years because of the support of that kind of rhetoric by the right-oriented government in Macedonia. In that sense, we can speak about a high continuity of methodological limitations that we have not to succeed to overcome till today when it comes to researching one's "own." Therefore, I consider that such historical reexamination of the narratives of the "national disciplines" is especially critical, not solely in terms of criticizing specific authors who should teach us how we should not write today, but rather in terms of finally overcoming the concepts of certain "schools" when it comes to researching "national topics". Margarita Karamihova, when talking about the Bulgarian context, says that the revision of the corpus of literature from the communistic period is an essential step for future development. Without a systematic collective analysis and a national debate, it is hard to know what has happened during the socialistic period, and it is also hard to determine what is supposed to happen in the post socialistic period in this sense (Karamihova 2017: 75). In the public discourse, there is an impression that the ethnocentric scientific discourse in the Macedonian "national disciplines" 
through history was more neutral, more silent, or less aggressive compared to the ethnocentric discourse in the neighboring "national disciplines." According to the above-presented examples, it is evident that the impression about the weak ethnocentrism of Macedonian "national disciplines" actually is a myth that exists precisely because of the lack of systematic analysis regarding the scientific discourse of the "national disciplines" in historical perspective.

According to the examples from the journal "Macedonian folklore" and its editions in the Yugoslav period, it becomes evident that there is a strong consensus among the researchers about their main task - determining the national affiliation of the folklore and there are almost no exceptions from this concept. Burdened with the national, folkloristic studies treat Macedonian people as "our people," as an essential and inseparable component of the scientific work, at the same time emphasizing the care of the science for its "own" people. The revival ideas are very current in this period, and they imply the glorification of folklore in favor of Macedonian national identity, especially revolutionary or historical folklore. The idealization of folklore implies the idealization of what is Macedonian. The historical contexts are always present even in the analyses that are not directly connected to the historical and revolutionary folklore. In favor of continuity of the ethnic existence, the folk culture and the tradition are treated as static and fixed through centuries. The authors vigorously search for unique, general characteristics of the topics they explore, and their specifics in most cases depend on the prefix 'ethno.' The idealization of the folk culture through the folkloristic analyses is an essential task in Macedonian folkloristic, which is always interpreting the Macedonian folk culture in positive light without deviations, pathologies, distortions. Foreign influences, those of neighboring cultures, are welcomed in the analyses when there is a need to explain the rare distortions or "deviations" from the idealized, imagined Macedonian. In every other case the mission of the folkloristic studies is to highlight the original, unique, pure Macedonian folk culture. Macedonian folkloristics is strongly dedicated to the obligation to protest against the appropriation of Macedonian folklore by the neighboring states. That is why the authors need to point to the unique character of the Macedonian folklore, which is geographically and ethnically determined, created on the "Macedonian soil" and with the common Macedonian characteristics. In that way, the folklore becomes a property of separate Balkan nations, which must differ from each other. All of the mentioned characteristics of the Macedonian folklore in the analyzed period increasingly involve the advocacy of "our people" by the authors in ethnocentric style rather than "objective" science in the positivistic sense of the word, which is declaratively emphasized as the chosen approach by most of the authors. Instead of the oxymoron: the objective science about the subjective national topics, Macedonian researchers from the "national disciplines" are still missing the reflexivity as a vital and useful methodological tool in this sense. The focus of researchers on their positioning about the topic of research can enable them to exit the frame in which they are 


\section{EthnoAnthropoZoom}

put, in a position to participate directly and actively in the process of (re)creation of national identity.

\section{Sources:}

Андонов-Полјански, Христо. 1972. „Особености од Македонија во британската етнолошка и фолклористичка литература“, Макеgонски фолклор 9-10: 231-240.

Вражиновски, Танас. 1976. „Кон проучувањето на народните кажувања (по примери на Народноослободителната борба)“, Макеgонски фолклор 18: 99-105.

Вражиновски, Танас. 1979. „Македонските преданија за места“, Макеgонски фолклор 23: 213-275.

Дискусија на II симпозиум за балкански фолклор. 1972. Макеgонски фолклор 9-10: 211-214.

Јаќоски, Воислав. 1983. „Преглед врз револуционерната народна песна од Штип и Штипско“, Макеgонски фолклор 32: 13-24.

Каровски, Лазо. 1968. „Ритмиката на народната поезија од епохата на Илинден“, Макеgонски фолклор 2: 47-55.

Најчески, Димче. 1968а. „Томе Саздов: Македонската народна поезија краток преглед“, Скопје: Култура, 1966; Макеgонски Фолклор 1: 194.

Најчески, Димче. 1968б. „Народните борбени песни од периодот пред организирањето на ВМРО“, Макеgонски фолклор 2: 35-41.

Најчески, Димче. 1969. „Илинденското востание во македонската народна поезија“, Макеgонски фолклор 3-4: 83-90.

Пенушлиски, Кирил. 1974. „Кон проучувањето на македонските еротски народни приказни“, Макеgонски фолклор 14: 67-85.

Попвасилева, Александра. 1980. „Цветана Романска: Въпроси на българското народно творчество“, во: Избрани студии и статии. Составиле, П. 


\section{EthnoAnthropoZoom}

Динеков и Ст. Стојакова, София 1976, 462, Макеgонски фолклор 26: $181-183$.

Ристовски, Блаже. 1970. „Дваесет години Институт за фолклор во Скопје“, Макеgонски фолклор 5-6: 5-8.

Ристовски, Блаже. 1973. „Три советски фолклористички зборника и еден нефолклористички проблем“, Макеgонски фолклор 11: 115-130.

Ристовски, Блаже. 1976. „Македонската револуционерна народна песна од Пулевски до Рацин“, Макеgонски фолклор 18: 91-98.

Робовски, Никифор. 1968. „Одразот на Илинден во македонската историска песна“, Макеgонски фолклор 2: 42-45.

Саздов, Томе. 1968. „Критики, рецензии, белешки: Българско народно творчество“. Т. I-XIII, София, 1961-1965, Макеgонски фолклор 2: 287-294.

Симитчиев, Коле. 1968. „По прашањето за потеклото на македонскиот народен еп“, Макеgонски фолклор 1: 41-54.

Симитчиев, Коле. 1984. „Македонски и бугарски варијанти на баладата за мајката, којашто присилена од Турците го фрла своето новороденче“, Македонски фолклор 33: 65-71.

Станковиќ Карчовска, Верица. 1987. „Некои ориентални елементи во македонската народна песна и творечкиот лик на Панка Хаџинаумова“, Макеgонски фолклор 39-40: 171-179.

Стоичковски, Благој. 1990. „Томе Саздов: „Македонска фолклорна литература“““, Македонска ревија, Скопје, 1987, 1-173, Макеgонски фолклор 46: $162-164$.

Стоичковски, Благој. 1991. „Свадбените обичаи во Пијанечко-Малешевскиот регион“, Макеgонски фолклор 47: 107-113. 


\section{References:}

Ристески, Љ. 2014. „Само што излеговме од опинци, етнолозите сакаат повторно да нѐ вратат во нив“. Статусот на етнологијата во Македонија во периодот на социјализмот (1946-1953), In: За еитнолойијайа... безброј иррайови сме ирреминале... За Анейа Свеишева, Ристески Љупчо, Ана Ашталковска Гајтаноска (eds.). 55-76. Скопје: ИЕА.

Čapo, J. 2014. 'Ethnology and Anthropology in Europe. Towards a Trans-National Discipline', Cultural Analysis 13: 51-76.

Čolović, I. 1994. Bordel ratnika, folklor, politika i rat, drugo izdanje. Beograd: Biblioteka XX vek.

Karamihova, M. 2017. 'Teaching Bulgarian Ethnology During Post-Communist Period', In: Against All Odds: Ethnology and Anthropology between Theory and Praxis, Risteski Lj., Ines Crvenkovska Risteska (eds.). 71-80. Skopje: IEA.

Mihăilescu, V., Iliev, I., Naumović, S. (yp.). 2008. 'Introduction', Studying Peoples in the People's Democracies II, Socialist Era Anthropology in SouthEast Europe. 1-18. Berlin: LIT-Verlag.

Prica, I. 2004/2005. Etnologija postsocijalizma i prije. Ili: Dvanaest godina nakon „Etnologije socijalizma i poslije“, Etnološka Tribina 27-28(34/35): 9-22.

Vukov, N. 2012. Ethnoscripts and nationographies: imagining nations within ethnographic museums in East Central and Southern Europe, Great Narratives of the Past. Traditions and Revisions in National Museums Conference proceedings from EuNaMus, European National Museums: Identity Politics, the Uses of the Past and the European Citizen, Paris 29 June 1 July \& 25-26 November 2011. Dominique Poulot, Felicity Bodenstein \& José María Lanzarote Guiral (eds) EuNaMus Report No 4. Linköping University Electronic Press, 331-343, <http://www.ep.liu.se/ecp home/index.en.aspx?issue $=078>$ accessed on: 12.12 .2018 .

Wilson, W. 1973. 'Herder, Folklore and Romantic Nationalism', Journal of Popular Culture 6(4): 819-835. 
EthnoAnthropoZoom 